\title{
A multicarpellate fruit from Late Cretaceous sediments of South Bohemia, Czech Republic
}

\author{
Zuzana Heřmanová, Jana Čepičková, Jiří Kvaček, \\ Maria von Balthazar, and Jürg Schönenberger
}

\begin{abstract}
The gynoecium of most angiosperms consists of two or more united carpels and syncarpy is generally considered a key innovation. Multicarpellate-syncarpous gynoecia, i.e., with more than five united carpels, are overall rare, probably because of developmental and functional constraints. Based on scanning electron microscopy (SEM) and X-ray computed tomography (microCT), we here describe a new fossil taxon, Covidifructus multicarpellatus, from the Late Cretaceous (Late Turonian-Santonian) of Southern Bohemia (Czech Republic). The new fossil taxon is based on a single syncarpous gynoecium (an immature fruit) consisting of 10 carpels, each containing a single seed; no other floral organs are preserved. The gynoecium morphology of C. multicarpellatus is highly complex and involves an enclosed, undifferentiated floral apex, an empty space in the centre of the ovary formed by the postgenital union of the distal parts of the carpels, an irregular apical closure of the ovary, and possibly an extra-gynoecial compitum. Similar gynoecium morphologies have evolved convergently in various angiosperm lineages and are directly linked with the special developmental (architectural) challenges of forming a functional syncarpous gynoecium with many carpels. Among extant angiosperms, C. multicarpellatus is most similar to Dillenia (Dilleniaceae). However, a systematic assignment based on gynoecium characters alone would involve a high level of uncertainty, even if the gynoecial features of $C$. multicarpellatus are rare among other angiosperms.
\end{abstract}

Zuzana Heřmanová. National Museum, Prague, 11000 Václavské náměstí 68, Prague 1, Czech Republic. zuzka.hermanova@gmail.com

Jana Čepičková. Institute of Geology and Palaeontology, Faculty of Science, Charles University, Albertov 6, Prague, 12843, Czech Republic and National Museum, Prague, 11000 Václavské náměstí 68, Prague 1, Czech Republic. jana.cepickova@nm.cz Jiří Kvaček. National Museum, Prague, 11000 Václavské náměstí 68, Prague 1, Czech Republic. jiri.kvacek@nm.cz

Heřmanová, Zuzana, Čepičková, Jana, Kvaček, Jiří, von Balthazar, Maria, and Schönenberger, Jürg. 2022. A multicarpellate fruit from Late Cretaceous sediments of South Bohemia, Czech Republic. Palaeontologia Electronica, 25(1):a5. https://doi.org/10.26879/1192 palaeo-electronica.org/content/2022/3525-a-fossil-multicarpellate-fruit

Copyright: January 2022 Paleontological Society.

This is an open access article distributed under the terms of Attribution-NonCommercial-ShareAlike 4.0 International (CC BY-NC-SA 4.0 ), which permits users to copy and redistribute the material in any medium or format, provided it is not used for commercial purposes and the original author and source are credited, with indications if any changes are made. creativecommons.org/licenses/by-nc-sa/4.0/ 
Maria von Balthazar. Department of Botany and Biodiversity Research, University of Vienna, Rennweg 14, A-1030 Vienna, Austria. maria.von.balthazar@univie.ac.at

Jürg Schönenberger. Department of Botany and Biodiversity Research, University of Vienna, Rennweg 14, A-1030 Vienna, Austria. juerg.schoenenberger@univie.ac.at

Keywords: angiosperms; compitum; Covidifructus multicarpellatus; floral morphology; fossil flower; syncarpy

Submission: 4 October 2021. Acceptance: 14 January 2022.

\section{INTRODUCTION}

Flowers with a gynoecium of several carpels that are free from each other (apocarpous) are most likely ancestral in angiosperms (Endress and Doyle, 2009; Doyle and Endress, 2011; Sauquet et al., 2017; Sauquet et al., 2018). Most extant angiosperms lineages, however, are characterized by a low number of congenitally united carpels (syncarpous), e.g., most monocots have three united carpels (Remizowa et al., 2010) and in eudicots, syncarpous gynoecia with two to five carpels prevail (Endress, 2011). Syncarpy is generally considered a key innovation in angiosperms (Endress, 2001a; 2011). Advantages of syncarpy over apocarpy include, for instance, more efficient pollination and seed/fruit dispersal strategies (Stebbins, 1974; Endress, 1982). However, the likely most important selective advantage of syncarpy may be the formation of a compitum, i.e., an intragynoecial pollen tube transmitting tract (PTTT), in which centralized male gametophyte selection across all the united carpels of a gynoecium is possible (Endress, 1982; Endress and Igersheim, 2000; Armbruster et. al, 2002). These advantages may be the reason why syncarpy was established multiple times independently early in the evolutionary history of angiosperms (see supplementary discussion of Sauquet et al., 2017).

While syncarpous gynoecia with two to five carpels are widespread, syncarpy involving more than five united carpels in a single whorl is relatively rare, the likely reasons involving developmental and functional/architectural constraints (Endress, 2006; Endress, 2014). To overcome these constraints, such multicarpellate-syncarpous gynoecia are often characterized by a series of specific structural differentiations (e.g., irregular gynoecium closure, centre of floral apex not involved in gynoecium formation; Endress, 2014). Among extant angiosperms, such multicarpellatesyncarpous gynoecia are generally rare but have evolved repeatedly in different clades. Well-known examples include representatives of Nymphaea L.
(Nymphaeaceae; e.g., Schneider and Williamson, 1993) among early diverging angiosperms, Alisma L. (Alismataceae; e.g., Kaul, 1976) among monocots, Papaver L. (Papaveraceae; e.g., Karrer, 1991) among early diverging eudicots, as well various lineages in the eudicots (Ronse De Craene and Smets, 1998; Endress, 2014). Several multicarpellate-syncarpous gynoecia are also known from the fossil record. Prominent examples include Monetianthus mirus (Nymphaeales) from the Early Cretaceous of Portugal (Friis et al., 2001; 2009), Carpestella lacunata from the Early Cretaceous of North America (possibly related to early diverging angiosperms; von Balthazar et al., 2008), and Elsemaria kokubunii (possibly Dilleniales) from the Late Cretaceous of Japan (Nishida, 1994).

Here, we report a new fossil taxon, Covidifructus multicarpellatus gen. nov. et $\mathrm{sp}$. nov, from the Late Cretaceous (Late Turonian-Santonian) of the Zliv - Rídká Blana Quarry locality in the South Bohemian Basins in Central Europe. The locality is known for other well-preserved, charcoalified angiosperm reproductive structures (Heřmanová et al., 2011, 2017). The Zliv - Řídká Blana flora is a typical Late Cretaceous flora, dominated by smallsized fruits and seeds of angiosperms together with occasional small angiosperm flowers and scattered fragments of ferns. More than half of these reproductive structures can be assigned to species or genera already described from the Klikov Formation or other localities in Europe (Knobloch and Mai, 1986); while the remainder of the structures probably represent new taxa. The systematic composition of the Zliv - Rídká Blana mesofossil flora is in agreement with other Late Cretaceous mesofossil floras from Laurasia. Diverse components related to the Normapolles group (Fagales) and taxa that appear to be related to Proteales, Laurales, and various families of the Ericales are particularly common (Heřmanová et al., 2021). In addition to the reproductive plant remains, the fossil assemblage also includes vegetative plant specimens such as leaves and wood 
pieces as well as insect eggs and coprolites. The palaeoclimatic analysis of the Klikov Formation flora using Nearest Living Relative and the Climate Leaf Analysis Multivariate Program (CLAMP) suggests a seasonally dry, paratropical to warm temperate climate (Váchová and Kvaček, 2009).

Covidifructus multicarpellatus is based on a single charcoalified and 3-dimensionally preserved specimen representing a 10-carpellate syncarpous gynoecium. The excellently preserved specimen provides detailed information on the complex ovary morphology that includes an irregular central closure of the ovary and an enclosed central floral apex, which remained undifferentiated during gynoecium formation. This new Cretaceous taxon adds to the growing paleobotanical evidence that the floral morphospace of Cretaceous angiosperms is in many respects congruent with that of extant flowers and includes also highly complex floral morphologies known in present day taxa.

\section{MATERIAL AND METHODS}

The fossil described here is based on a single specimen (catalogue number NM-F 3200) and was isolated from sediments housed in the National Museum, Prague. The sediments were collected in summer 2007 by Zuzana Heřmanová and Jiří Kvaček from the Zliv - Ř́dká Blana Quarry $10 \mathrm{~km}$ from České Budějovice (coordinates: $49.0801556 \mathrm{~N}, 14.3850450 \mathrm{E})$. The mesofossil was extracted from a thin layer of dark sand within grey sandy-claystone by bulk maceration using bicarbonate, followed by washing on a $90 \mu \mathrm{m}$ sieve. After sieving, the organic residue was first treated for ca 24 hours with hydrofluoric acid and then for another 24 hours with hydrochloric acid. Then the organic residue was rinsed in water and dried in air. The mesofossil material retrieved from these sediments is mostly preserved as three-dimensional charcoalified fossil structures. Sorting and preliminary studies were processed under a binocular microscope Olympus SZX-12 (Tokyo, Japan). For SEM, the specimen was mounted on an aluminium stub using nail polish, coated with gold and studied with a Hitachi S-4300 and a Hitachi S3700 (Tokyo, Japan) field emission scanning electron microscope. Subsequently, the specimen was studied by X-ray micro-tomography using a SkyScan 1172 from Bruker (Billerica, Massachusetts, USA). The effective pixel size was ca. $0.5 \mu \mathrm{m}$. Tube voltage was set to $40 \mathrm{kV}$, and the current source was $250 \mu \mathrm{A}$. No filter was used. The acquired data were processed using flat field correction and reconstructed by the supplied software
NRecon from Bruker (Billerica, Massachusetts, USA). Photographs were made using the Thermo Fisher Scientific ${ }^{\mathrm{TM}}$ Avizo 9.4 software package (Waltham, Massachusetts, USA). The presented figures were further edited using Adobe Photoshop CS5 and Adobe Illustrator CS5 (San Jose, California, USA). Tiff-stacks of the microCT reconstructions are deposited on the public repository https:// phaidra.univie.ac.at/o:1287574 where they can be downloaded. The new names of the genus and species (see below) are registered with a unique PFN number in the Plant Fossil Names Registry, hosted and operated by the National Museum, Prague for the International Organisation of Palaeobotany (IOP).

\section{Geology}

The Zliv - Řídká Blana Quarry displays a section in the Klikov Formation (Late Turonian-Santonian) in the South Bohemian Basins. The basins consist of two elongated depressions, the Třebon Basin and the České Budějovice Basin separated by the Lišov Horst. The two subbasins together occupy an area of about $2300 \mathrm{~km}^{2}$. They are developed on the Moldanubian crystalline bedrock of the Bohemian Massif. Sedimentation in both basins began in the Late Cretaceous and continued intermittently until the Pliocene (Slánská, 1974).

The deposits of the Klikov Formation are present in both basins with a mean thickness of 100$150 \mathrm{~m}$ and constitute the most widely distributed stratigraphical unit in the South Bohemian Basins (Slánská, 1974). The sediments consist of: (A) light grey or yellow conglomeratic, coarse to medium grain sandstone beds, (B) generally fine-grained red beds, and $(C)$ grey mudstone beds. These bed three types form asymmetrical cycles (Slánská, 1976).

\section{RESULTS}

\section{Systematics}

Genus COVIDIFRUCTUS Heřmanová, Čepičková, J. Kvaček, von Balthazar, Schönenberger gen. nov

Derivation of generic name. The first part of the genus name refers to the period of the Covid-19 pandemic, when we found time to collaborate on this project; the second part of the name refers to the fact that this new genus is based solely on a fruit specimen.

Generic diagnosis. Gynoecium syncarpous, multicarpellate (10 carpels in radial symmetry), ovary 
superior with 10 locules; empty space in the centre of the ovary above remaining floral apex, central ovary closure irregular, placentation axile in the apical part of the locule, each of the 10 locules with a single, oblong ovule/seed filling out its locule almost completely; lines of dehiscence located on the median-dorsal side of each carpel (loculicidal dehiscence of the fruit).

Type species. Covidifructus multicarpellatus Heřmanová, Čepičková, J.Kvaček, von Balthazar, Schönenberger sp. nov.

\section{Plant Fossil Names Registry Number.} PFN002713 (for new genus).

Covidifructus multicarpellatus sp. nov.

Figures $1 \mathrm{~A}-\mathrm{F}, 2 \mathrm{~A}-\mathrm{I}, 3 \mathrm{~A}-\mathrm{B}$

Derivation of species name. The specific epithet (multicarpellatus) refers to the numerous (10) carpels of the fossil.

Species diagnosis. Same as generic diagnosis.
Dimensions. $0.75 \mathrm{~mm}$ in diameter and $0.5 \mathrm{~mm}$ in length.

Holotype. No. NM-F 3200, housed in the National Museum Prague.

Plant Fossil Names Registry Number. PFN002714 (for new species).

Type locality. Zliv - Ř́dká Blana.

Type stratum. Klikov Formation, Late Cretaceous, late Turonian-Santonian Age.

Description and Remarks. The description is based on the sole specimen of this taxon that was found so far. Since the specimen exhibits distinct but unseparated lines of dehiscence on the carpels (Figure 1A-B) and contains 10 seeds (Figure 1DE), we interpret it as an immature, capsular fruit. The specimen is charcoalified and 3-dimensionally preserved. While the preservation of the material is not sufficient to study internal histological details (e.g., the vasculature), it allows for a full description of the basic morphology of the ovary and, although
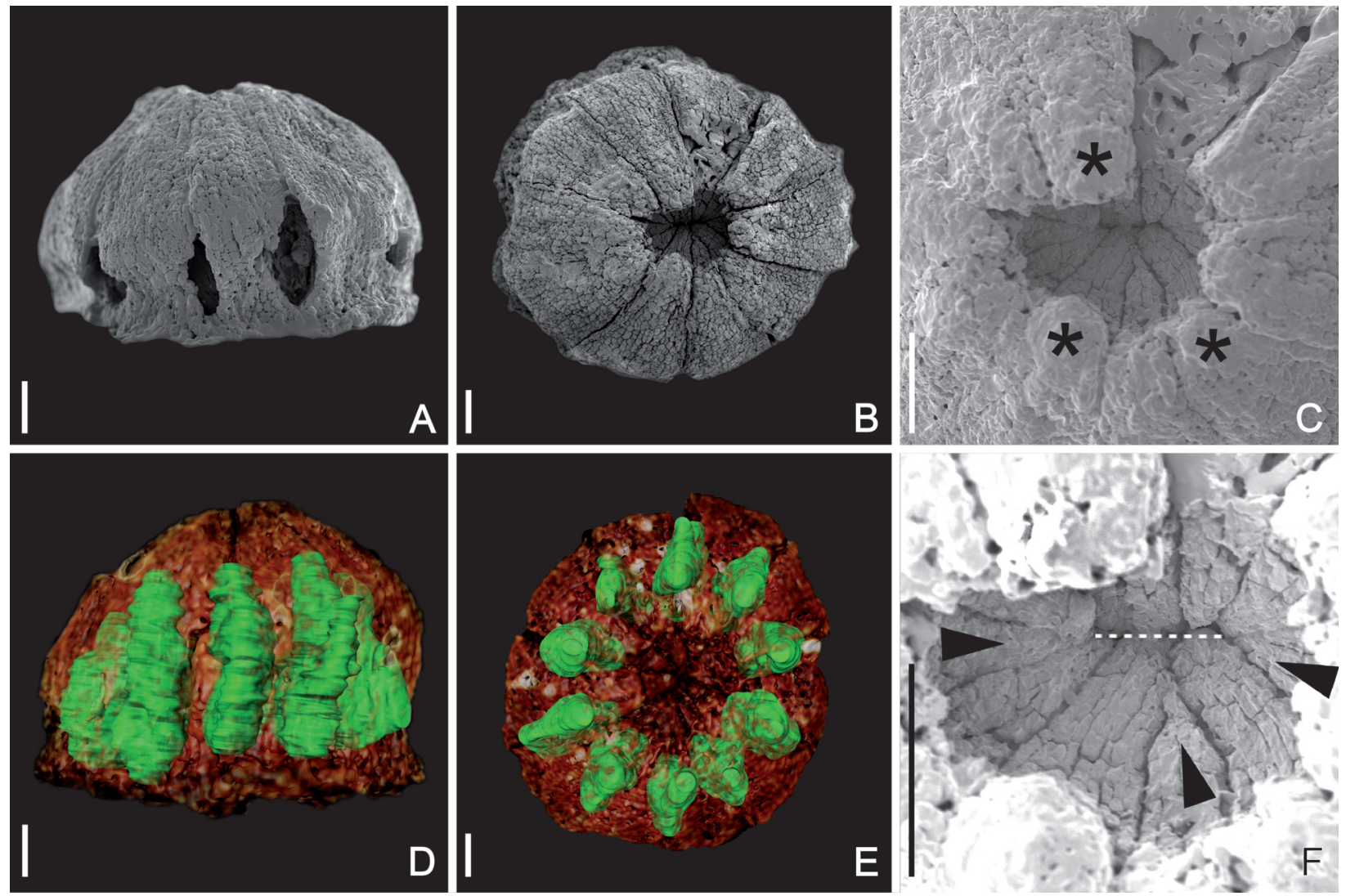

FIGURE 1. Covidifructus multicarpellatus gen. et sp. nov.; specimen No. NMP F3200; scale bars equal $100 \mu \mathrm{m}$ in all figures. (A) Small premature capsular fruit in lateral view, semi-globose in overall shape; SEM. (B) Fruit seen in apical view; note preformed dorsal lines of fruit dehiscence; SEM. (C) Close-up of fruit apex showing styles and stigmatic areas (asterisks); note irregular closure of ovary in the very centre; SEM. (D) MicroCT volume rendering, lateral view, showing 10 elongate seeds (green), one seed per carpel. (E) MicroCT volume rendering, apical view, showing regular arrangement of carpels and seeds. (F) Detail of central ovary closure (dashed line); note that some of the carpel flanks (arrowheads) do not extend to the very centre of the closure zone; SEM. 

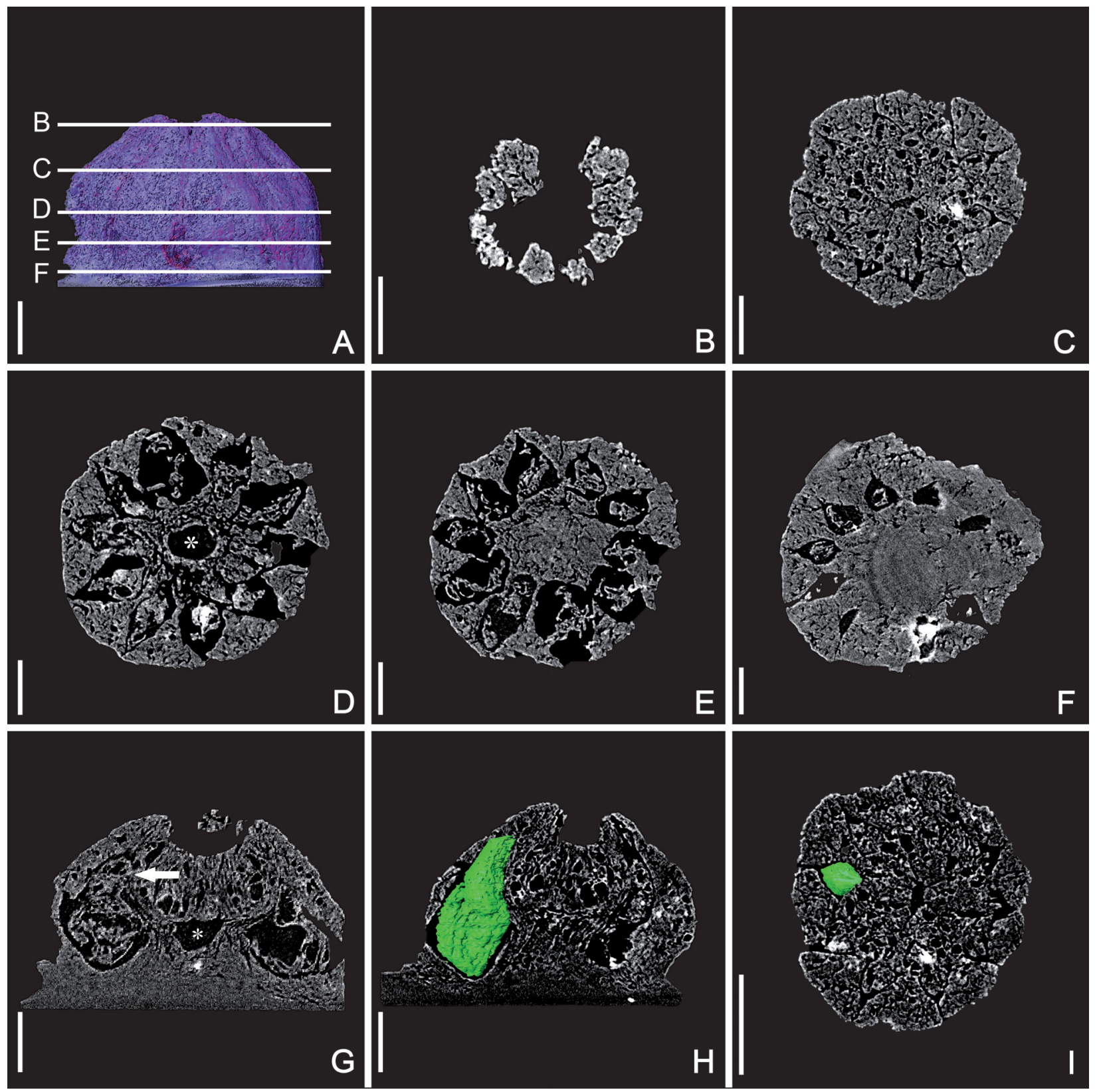

FIGURE 2. Covidifructus multicarpellatus gen. et sp. nov. specimen No. NMP F3200, scale bars equal $300 \mu \mathrm{m}$ in all figures, series of microCT sections of premature capsular fruit. (A) Volume rendering of fruit in lateral view; lines B-F indicate approximate levels of transverse sections shown in the following images. (B) Transverse section at the level of styles and stigmas. (C) Transverse section at the level of the symplicate zone of the gynoecium where the carpels are postgenitally united in the centre of the ovary; distalmost parts of locules and seeds are visible. (D) Transverse section at the level of the empty space (asterisk) where carpels do not meet in the centre of the ovary. (E) Transverse section at the level of the synascidiate zone of the gynoecium, i.e., below the enclosed floral apex and the empty space. ( $F$ ) Transverse section through the very base of the fruit showing the basal-most parts of the locules. (G) Longitudinal median section showing empty space in the centre of the ovary (asterisk) and axile ovule/seed attachment (arrow) in the distalmost part of the ovary. (H) Longitudinal tangential section with one seed rendered and coloured in green. (I) Transverse section at the level of seed attachment in the distal part of the ovary, with one seed rendered and coloured in green. 

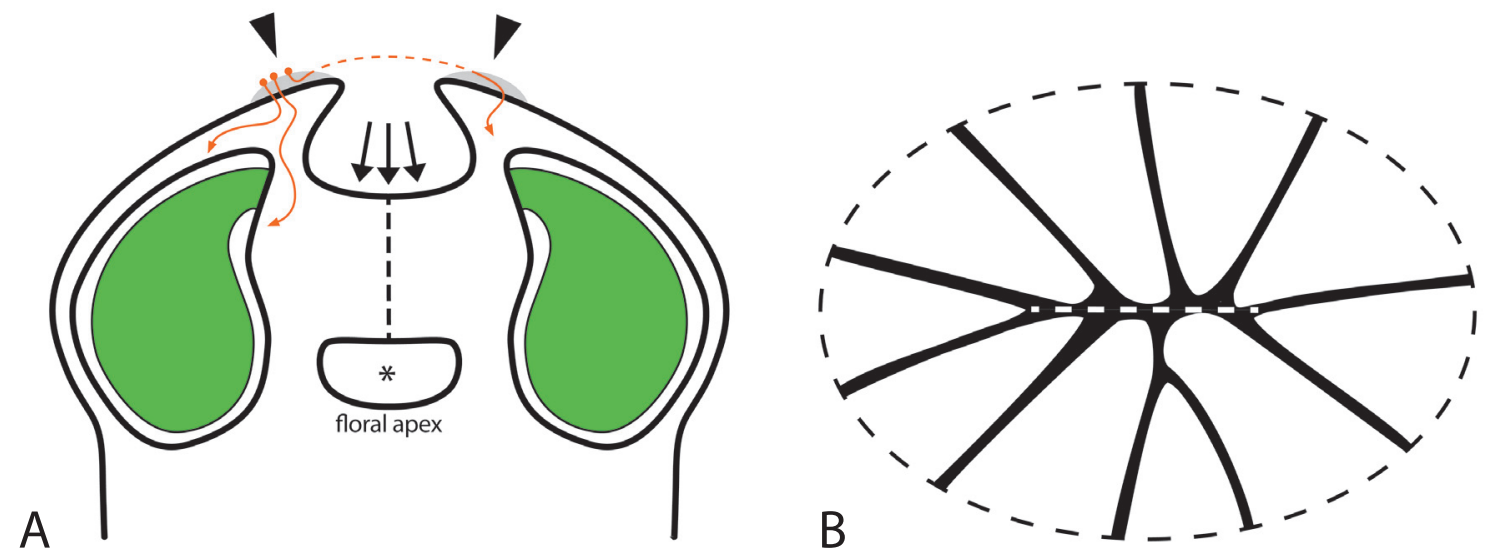

FIGURE 3. Schematic line drawings of the gynoecium of Covidifructus multicarpellatus. (A) Longitudinal median section through the gynoecium showing its complex internal morphology with a remaining floral apex and an empty space (asterisk) in the centre of the ovary; arrowheads indicate stigma positions; grey shaded areas indicate potential stigmatic secretion forming an extra-gynoecial compitum across neighbouring stigmas; pollen grains and hypothetical pathways of pollen tubes are given in orange; dashed orange line indicates hypothetical pathway of pollen tube reaching a stigma via growth through the extra-gynoecial compitum; dashed black line indicates area of postgenital carpel union in the centre of the ovary (symplicate region); arrows indicate area of irregular ovary closure shown in (B); placentation is axile with the seeds (green) attached in the distalmost part of the ovary. (B) Line drawing showing zone ovary closure (see also Figure $1 \mathrm{C}, \mathrm{F}$ ) as seen from above, radial lines correspond to ventral slits of individual carpels; carpel flanks meet in an irregular pattern in the centre of the gynoecium; the area of closure is flattened (compressed; indicated by dashed ellipse), and the 10 carpels are roughly arranged in a double row facing each other (dashed line in centre of figure) rather than in a smooth circle.

with less detail, also of the seeds. Other floral organs are not preserved.

With $0.75 \mathrm{~mm}$ in diameter and $0.5 \mathrm{~mm}$ in length (from the base of the ovary to the carpel tips), the fruit is tiny. The ovary is syncarpous and multicarpellate, consisting of 10 carpels (Figure $1 \mathrm{~B}-\mathrm{E})$. As there are no traces (scars) of other floral organs on the outer surface of the ovary, it must have been in superior position in the intact flower. The ovary is semi-globose in overall shape with a shallow constriction close to its base (Figure 1A). The lines of dehiscence are located on the median, dorsal side of each carpel (Figures 1B, 2D-F), which indicates loculicidal opening of the fruit. Close to the base of the ovary, several holes are present (Figure 1A). As these holes are irregular in shape and are only present on one side of the specimen (Figure 2D-E), they are most likely the result of damage that happened during charcoalification or transport before the specimen became buried in the sediment.

The morphology of the ovary is characterized by a series of special features (Figure $3 \mathrm{~A}$ ). In the middle section of the ovary, the 10 carpels are united only along their flanks (and not in the centre), leaving an empty space in the centre of the ovary (asterisks in Figures 2D, G, 3A). Distally to this empty space, the carpels meet in the centre and are apparently postgenitally united (symplicate zone; Figures 2C, G-I, 3A). The morphological surface and the underlying tissue (Figure 2E-G) delimiting the central empty space towards the base of the ovary (i.e., the synascidiate zone), corresponds to the remaining floral apex, which was not involved in gynoecium formation. In addition, central ovary closure in the postgenitally united zone is not regular (as seen from above in Figures $1 \mathrm{C}, \mathrm{F}$, $3 B$ ), i.e., some of the carpel flanks do not extend to the very centre of the closure zone (Figures $1 \mathrm{~F}$ [arrowheads], 3B). In addition, the ovary closure zone (arrows in Figure 3A) is not circular (when seen form above) but slightly flattened (compressed) and the carpels face each other along a short suture (dashed lines in Figures 1F, 3B). The distalmost parts of the carpels (the styles) extend beyond the zone of ovary closure, together forming the cup-shaped top of the ovary (Figures 1B, 2B, $\mathrm{G}-\mathrm{H}, 3 \mathrm{~A}$ ). The carpels are united along their flanks over most of their length. Whether their tips (the styles) are free (which would correspond to an asymplicate zone) cannot be established unequivocally because they are partly damaged (Figures $1 \mathrm{C}, 2 \mathrm{~B})$. It is likely that the carpel tips correspond to stigmatic areas (asterisks in Figure 1C, arrow- 
heads in Figure $3 A$ ). This is supported by the relatively uneven epidermis in the region of the carpel tips (Figure 1B-C). These tips may also show remnants of a stigmatic secretion (asterisks in Figure $1 C)$, which in turn may have functioned as an extra-gynoecial compitum spanning all 10 carpels. However, this cannot be established with certainty. In other parts of the ovary surface, the epidermis is generally more or less smooth and neither trichomes nor stomata are present (Figure 1A, C, F).

Each of the 10 locules contains a single, oblong seed that fills out its locule almost completely (seeds shown in green in tomographic reconstruction in Figures 1D-E, 2H-I, and in schematic drawing Figure $3 \mathrm{~A}$ ). Placentation is axile with the seed attached in the upper part of the locule (Figures 2G [arrow], 3A) and pendant in the locules. Structural details of the seeds cannot be established.

Note. The single specimen (Holotype no. F3200) of Covidifructus multicarpellatus was previously mentioned briefly as "Taxon 20" and illustrated with a single SEM picture in figure $7 \mathrm{~g}$ of Heřmanová et al. (2021).

\section{DISCUSSION}

Syncarpous gynoecia with a higher number of carpels (10 or more) in a single whorl as in the fossil described here, are rare in the fossil record (Friis et al., 2011) as they are also among extant angiosperms, particularly so among early diverging lineages and magnoliids. However, such multicarpellate-syncarpous gynoecia are present in various monocot and eudicot lineages (see Endress, 2014). In the following, we discuss some of the special functional aspects of the complex architecture of the gynoecium of Covidifructus multicarpellatus. Subsequently, we compare C. multicarpellatus with selected multicarpellate Cretaceous fossils and for the comparison with extant angiosperms, we focus on taxa that combine an irregular closure of the ovary with a remaining, undifferentiated floral apex. Our selection of discussed extant taxa is based on the extensive literature review on multicarpellate gynoecia provided by Endress (2014).

\section{Unusual Architectural and Functional Aspects}

In syncarpous gynoecia, the compitum, i.e., the zone of the pollen tube transmitting tract (PTTT) where centralized pollen tube competition takes place and where pollen can move from one carpel to another, is usually located in the symplicate zone of the gynoecium (intra-gynoecial compi- tum; Endress, 2011). However, a special type of compitum may also be formed outside the gynoecial tissue. In some multicarpellate but apocarpous gynoecia or in syncarpous gynoecia with unusual architectures, connection of stigmas (and therefore the formation of an extra-gynoecial compitum) is possible by secretion or just contiguity by which pollen tubes can pass from one carpel to another (Endress, 2011). Such an extra-gynoecial compitum has for instance been reported for the multicarpellate-syncarpous gynoecia of Nymphaea L. (Endress, 1982) and Illicium L. (Schisandraceae; Williams et al., 1993). While it is impossible to unequivocally establish the PTTT and a potential extra-gynoecial compitum in C. multicarpellatus, its special gynoecial architecture allows us to develop a plausible hypothesis on how the pollen tube may have reached the ovules. As pointed out by Endress (2014), a centralized, intra-gynoecial compitum is difficult to establish in gynoecia in which ovary closure is irregular and the centre of the floral apex is not used up during ovary formation. Both of these conditions are present in C. multicarpellatus and it is, therefore, unlikely that there was a functional intra-gynoecial compitum. Instead, the closely aligned styles and stigmatic areas as well as the potential remnants of stigmatic secretion, may indicate that $C$. multicarpellatus had an extra-gynoecial compitum (as indicated by the grey-shaded area in Figure $3 \mathrm{~A}$ ). Further, it seems plausible that pollen tubes did not grow through the centre of the symplicate zone of the gynoecium (area of postgenital carpel union indicated by dashed black line in Figure $3 \mathrm{~A}$ ), as this would have required a much longer PTTT. A more parsimonious possibility is that the pollen tubes grew directly towards the apical parts of the ovary locules (orange lines indicate potential pollen tube pathways in Figure $3 \mathrm{~A}$ ), where the ovules were attached and, under the assumption that the ovules were anatropous, where the micropyles were to be found.

\section{Comparison with Selected Other Fossil Flowers}

Elsemaria kokubunii is known from a single permineralized fruit from the Late Cretaceous (Coniacian-Santonian) of Japan (Nishida, 1994). As in Covidifructus, the gynoecium consists of 10 united carpels with axile placentation and likely represents a loculicidal capsule. Elsemaria kokubunii may also be similar in that the 10 carpels are only united along their flanks (and not in the centre), leaving an empty space in the centre over part of the ovary's length. In addition, some of the 
original figures in Nishida (1994, figs. 3c, 4) indicate that the ovary closure zone may be flattened (compressed) as it is in the fruit described here. However, some morphological features of $E$. kokubunii, as they were described by Nishida (1994), are more difficult to interpret. For instance, Nishida (1994) describes central "intercarpellary structures" interpreted as reduced carpels that are structurally independent form the 10 fertile carpels. Based on the figures in Nishida (1994), this interpretation seems at least doubtful as none of the figures shows any clearly independent structures in the centre of the ovary of $E$. kokubunii. In addition, a gynoecium construction with 10 united carpels in an outer whorl and 10 apparently free, reduced carpels in the centre seems unlikely from a developmental and functional point of view. A more parsimonious and morphologically plausible interpretation of these central structures of $E$. kokubunii is that they simply correspond to the proliferating margins of two neighbouring united carpels. As these carpel margins contain various vascular bundles (vertical ventral bundles from which horizontal bundles branch of towards the placenta and the ovules), the tissue may appear to stand out against the tissue of the ovary septa and give the false impression of constituting independent structures (for a similar case in an extant species, Dillenia alata (R.Br. ex DC) Banks ex Martelli, see Endress, 2014, figure 16). With this latter interpretation, E. kokubunii, may have the same basic gynoecium morphology as Covidifructus and a closer systematic affinity of these two fossil taxa seems possible. A feature in which the two fossil taxa differ, is the number of ovules. E. kokubunii has numerous (ca. 40) ovules/seeds per carpel (Nishida, 1994) while in the fossil fruit described here, each carpel contains a single ovule/seed. The systematic affinities of $E$. kokubunii are uncertain (Friis et al., 2011). In the original study, Nishida (1994) mentioned similarities to representatives of what was then called the superorder Dilleniidae, a broad assemblage of various eudicot families and orders (e.g., Dilleniaceae, Paeoniacieae, Passifloraceae, Theaceae) now no longer thought to be closely related (see also Friis et al., 2011).

Archaestella verticillatus represents a fossil flower with approximately 10 united carpels known from three charcoalified specimens (one floral bud/ flower and two fruiting specimens) from the Late Cretaceous (early Coniacian) of Japan (Takahashi et al., 2017). Based on the original description and images, the exact morphological structure of the gynoecium of $A$. verticillatus is difficult to establish.
While the ovary is described as semi-inferior, the flower is also mentioned to have a "perigynous perianth" (Takahashi et al., 2017; perigyny usually refers to flowers with a superior ovary and a hypanthium), and it is not clear whether there is a truly inferior part of the ovary. What seems clear is that the carpels are arranged in a single whorl and are likely united proximally into a relatively short syncarpous part. The structure of the much larger distal part of the gynoecium (the level of the placentae and ovules) is described as consisting of "laterally connate but distally distinct" carpels. Whether these distal parts of the carpels are laterally united or whether they are just packed closely to each other but are essentially free from each other cannot be established (see also Takahashi et al., 2017). What is clear is that the carpels are not united in the centre of the ovary over almost their entire length, leaving a distinct cavity in the centre of the flower. It is also clear that each carpel contains about 10 ovules/seeds (type of placentation is not described) and has a recurved style with a distinct, broadly rounded stigmatic area. Based on this incomplete morphological description of the gynoecium of $A$. verticillatus, a detailed comparison with Covidifructus is difficult. Similarities include the high number of carpels arranged in a single whorl and possibly carpels being united only along their flanks but not in the centre of the ovary. Covidifructus differs in having a more complex ovary structure with a proximal synascidiate region, an intermediate region where the carpels do not meet in the centre of the ovary, and a distal region where the carpels are postgenitally united in the centre leaving an empty, internal space above the undifferentiated remainder of the floral apex. In addition, Covidifructus differs from $A$. verticillatus in having no distinct stigma and only one ovule/seed per carpel. Taken together, these differences make a close systematic affinity of these two fossil taxa unlikely. Based on morphological similarities mainly in the androecium and gynoecium, Takahashi et al. (2017) referred $A$. verticillatus to the early diverging eudicot family Trochodendraceae, which seems plausible.

Finally, the fossil genus Nordenskioeldia (Heer) has multicarpellate gynoecia and is generally associated with Trochodendraceae and related families (Crane et al, 1991; but see Doweld, 1998). This taxon is mainly based on woody infructescence axes from various Paleocene localities in the Northern Hemisphere but is known from the Late Cretaceous to the Miocene (Crane et al., 1991; Friis et al., 2011; Manchester et al., 1991; Man- 
chester et al., 2021; Wang et al., 2009). Despite the many specimens that have been found, the gynoecium structure of Nordenskioeldia is not well understood and from the current descriptions, it is not entirely clear whether the fruits are truly syncarpous or rather correspond to an aggregation of apocarpous fruitlets. Also, the widespread belief that Nordenskioeldia is closely related to Trochodendraceae seems at least questionable based on the columellate structure in the centre and the umbrella-shaped structure at the base of the former taxon (Doweld, 1998; Manchester, et al., 2021). Among extant angiosperms, a taxon with a gynoecium that is in many respects similar to that of Nordenskioeldia, is the monotypic asterid genus Paracryphia Baker f. (Paracryphiaceae), which has multicarpellate-syncarpous gynoecia of 8-15 carpels. At the fruiting stage, the carpels detach (at least distally) from each other and from the solid centre of the gynoecium that remains as a persistent columella. In addition, Paracryphia shares with Nordenskioeldia that after detachment, the individual carpels open along their ventral margins releasing winged seeds (Dickison and Baas, 1977). With Covidifructus, Nordenskioeldia shares a single seed per carpel, but like Trochodendraceae, Covidifructus lacks a columella and such an umbrella-shaped structure at the base of the gynoecium. In addition, the fossil described here differs clearly in its complex internal gynoecium morphology from Nordenskioeldia. A closer relationship between these two fossil taxa is, therefore, unlikely.

\section{Comparison with Extant Taxa}

Among early diverging angiosperms, the combination of numerous united carpels and a remaining undifferentiated floral apex, is present in Nymphaeaceae (Nymphaeales) and Schisandraceae (Austrobaileyales). In the genus Nymphaea (Nymphaeaceae), the gynoecium is syncarpous and the carpels (up to 47) are arranged around a distinctive central protrusion of the floral apex (Igersheim and Endress, 1998). This protrusion often reaches the distal end of the carpels and is thus exposed even in anthetic flowers (e.g., Igersheim and Endress, 1998). Two fossil multicarpellate-syncarpous flowers, Monetianthus mirus (Nymphaeales) from the Early Cretaceous of Portugal (Friis et al., 2001; 2009) and potentially also Carpestella lacunata (possibly related to early diverging angiosperms) from the Early Cretaceous of North America (von Balthazar et al., 2008) are characterized by an exposed, remaining floral apex. Similarly, also the multicarpellate flowers (with up to 21 carpels) of Illicium (Schisandraceae) have such a central protrusion (Endress, 2001b), but in this case, the carpels are essentially free from each other (Igersheim and Endress, 1997). The gynoecia of both Nymphaea and Illicium are clearly different from that of Covidifructus multicarpellatus as, in the latter taxon, the remaining floral apex is not elevated and is enclosed in the centre of the ovary. Furthermore, placentation differs between Nymphaeales (laminar diffuse, numerous ovules), Illicium (near-basal ventral-median; Igersheim and Endress, 1997) and C. multicarpellatus with its near apical, axil placentation. A closer relationship of $C$. multicarpellatus with Nymphaeaceae, Schisandraceae, or any other early diverging angiosperm lineage can, therefore, be ruled out.

Among monocots, gynoecia with multiple carpels in a single whorl and a remaining floral apex in the centre are present, for instance, in the Alismatales and Pandanales but are rare or absent from other lineages (Endress, 2014; other multicarpellate monocots have mostly two or more whorls of carpels). However, gynoecium morphology of multicarpellate-syncarpous monocots is much simpler than in Covidifructus. The multicarpellate gynoecia in Alismatales, for instance, are essentially apocarpous above the level of carpel insertion on the floral base and the carpels usually remain ventrally open, even at the time of anthesis (Kaul, 1976), a condition that is clearly different from the gynoecium of Covidifructus. A closer relationship of Covidifructus with monocots seems very unlikely.

Among basal eudicots, the anthetic gynoecium of Trochodendron aralioides Siebold and Zucc. (Trochodendraceae, Trochodendrales) is similar to Covidifructus in that carpels are united congenitally in their proximal region, free in their mid-section, and postgenitally united further distally, leaving an empty space above the undifferentiated, remaining floral apex (see figure 40 in Endress, 1986). The gynoecium, however, differs is some characters such as the placentation, the differentiation of the style and stigma, and the presence of dorsal carpel nectaries in Trochodendraceae (Endress, 1986). Furthermore, Trochodendrales have ventricidal and only slightly loculicidal fruits (Endress, 1993; see also discussion on the fossil genus Nordenskioeldia above), a feature that is clearly different from the condition found in Covidifructus.

Among core eudicots, there are also a few taxa that show similarities in gynoecial characters 
with the Covidifructus. In particular, the genus Dillenia L. (Dilleniaceae, Dilleniales) exhibits a combination of gynoecium characters that closely matches what we found for Covidifructus. Dillenia flowers have 7-13 united carpels (Endress, 1997; 2014). As described by Endress (2014), in the proximal part of the ovary, the carpels are united only along their flanks (but not in the centre) leaving an empty space above the remaining floral apex. Distally to this empty space, the carpels meet in the centre and the ovary is closed through postgenital fusion in the centre (see in Endress, 2014, figure 17). This basic ovary architecture closely matches that of Covidifructus. In addition, Dillenia is similar to Covidifructus in the irregular pattern of central, postgenital ovary closure with only part of the carpel shoulders reaching the very centre of the ovary (Endress, 2014). Dillenia differs from Covidifructus in having elongate, horizontally oriented (reflexed), free styles with the stigma located at the tip (Endress, 2014). The number of ovules/seeds per carpel varies (one to many) among extant Dillenia species (Stevens, 2001 onwards; Endress, 2014). The quite substantial similarities in the highly complex gynoecium morphology between the extant genus Dillenia and $C$. multicarpellatus support their potential systematic affinity. However, in our view, gynoecium characters alone are insufficient to refer C. multicarpellatus to any extant lineage (see also discussion below).

Among rosid eudicots, the three closely related families Burseraceae, Anacardiaceae, and Kirkiaceae (Sapindales) generally have a low number of carpels. However, Beiselia Forman (Burseraceae), Pleiogynium Engl. (Anacardiaceae; for fossil (cenozoic) representatives of Pleiogynium, see Rozefelds et al., 2015), and some Kirkia Oliv. species (Kirkiaceae) are multicarpellate with up to 12 carpels (Bachelier and Endress, 2008; 2009). In these multicarpellate taxa, the gynoecium is characterized by an undifferentiated floral apex in its centre. While it is exposed in the anthetic flowers of Pleiogynium and Kirkia, it is enclosed in Beiselia as the carpel tips are postgenitally united above the apex, forming a short empty space above the synascidiate region (Bachelier and Endress, 2009). This special gynoecium morphology of Beiselia resembles what we describe here for the multicarpellate gynoecium of Covidifructus. However, all of these extant taxa differ from Covidifructus in that the synascidiate part of their gynoecia is much longer and in Beiselia, even extends beyond the locules while the symplicate zone remains rela- tively short (Bachelier and Endress, 2008; 2009). Stigmas are diverse in the three extant families. Often the styles are contiguous, or the carpel tips are postgenitally united with the wet, stigmatic areas forming an extra-gynoecial compitum (Bachelier and Endress, 2008, 2009), a condition, although difficult do establish, may also be present in Covidifructus. Another similarity between these extant taxa and Covidifructus is that each carpel contains only one (Anacardiaceae, Kirkiaceae) or two ovules (Burseraceae), which are pendant from axile placentae (Bachelier and Endress, 2008, 2009). The fossil gynoecium differs, however, from the extant taxa discussed here in that its styles are curved towards the centre of the gynoecium in the former but are reflexed in the latter (Bachelier and Endress, 2008, 2009). Based on the differences in style/stigma morphology and especially in the relative proportions of synascidiate vs. symplicate regions of the ovary, we consider a close relationship of these sapindalean lineages to $C$. multicarpellatus unlikely.

Yet another sapindalean lineage, the genus Peltostigma Walp. (Rutaceae), has normally 6-10 carpels (Engler, 1897) and the gynoecium structure resembles that of Covidifructus and the other sapindalean taxa discussed above. Also in Peltostigma, the carpels are only united laterally with each other at the level of the ovary and, more distally, the carpels are postgenitally united across the floral centre leaving an empty space in the centre of the ovary (see Engler, 1897). One or two ovules are present in each carpel (Engler, 1897; Appelhans et al., 2021). As in Covidifructus, fruits are capsular. However, a feature in which Peltostigma clearly differs from C. multicarpellatus is that in the former genus, the carpels open along their ventral slits at fruit maturity (Engler, 1897), making a closer relationship unlikely.

Finally, among asterid eudicots, many Araliaceae (Apiales) have an increased number of carpels (Nuraliev et al., 2010; Endress, 2014). As in Covidifructus, carpels unite postgenitally in the floral centre and enclose the remaining floral apex and, when carpels are present in very high numbers, ovary closure is irregular (Endress, 2014; Nuraliev et al., 2014). It is not clear how the area below the closed carpels is differentiated. Similar to Covidifructus, ovule number is low and generally only one seed per carpel develops in representatives of Araliaceae (Nuraliev et al., 2019). However, unlike in C. multicarpellatus, the ovary is usually at least partially inferior (Simpson, 2010), which makes a relationship with our fossil unlikely. 


\section{Potential Systematic Affinities and Conclusions}

In summary, the gynoecium of C. multicarpe/latus shares a series of salient morphological features with various extant and fossil multicarpellatesyncarpous taxa. The most important similarities include an undifferentiated floral apex that was not used up during flower development, an empty space in the centre of the ovary formed by the postgenital union of the distal parts of the carpels, and an irregular apical closure of the ovary. Among the extant taxa discussed here, the gynoecium structure of $C$. multicarpellatus is most similar to that of Dillenia and a closer systematic relationship to this genus or at least to the family Dilleniaceae seems possible. Such a relationship may be further supported by the morphological similarities of $C$. multicarpellatus with the Cretaceous fossil flower Elsemaria kokubunii (Nishida, 1994), which may also be related to Dilleniaceae. However, we decided, for the time being, to refrain from assigning C. multicarpellatus to Dilleniaceae or Dilleniales for two main reasons: first, a systematic assignment based on gynoecium characters alone would leave a high level of uncertainty, even if the observed combination of the special gynoecial features is rare among other angiosperms. The availability of only a few gynoecium characters makes it also impossible to include C. multicarpellatus into explicit and meaningful phylogenetic analyses based on an angiosperm-wide morphological data set (Schönenberger et al., 2020). Second, the special features mentioned above have apparently evolved convergently in various angiosperm lineages and are directly linked with the special developmental (architectural) challenges of forming a functional syncarpous gynoecium with many carpels (Endress, 2014). This reduces the power of these features to provide a reliable phylogenetic signal for the systematic placement of $C$. multicarpellatus. Hopefully, the future recovery of additional and more complete specimens will allow for a more precise systematic placement of Covidifructus.

\section{ACKNOWLEDGEMENTS}

We thank S. Pamperl for help with depositing the microCT data in a public repository and $S$. Manchester and P. Herendeen for their very helpful reviews of our paper. ZH was supported by the Czech Ministry of Culture (IP DKRVO 2019-2023 2.II.d, National Museum, 00023272), JK was supported by the Czech Grant Agency (project 2006134S) and JČ acknowledged support by the project "Grant Schemes at CU" (reg. no. CZ.02.2.69/0.0/0.0/19_073/0016935).

\section{REFERENCES}

Appelhans, M.S., Bayly, M., Heslewood, M.M., Groppo, M., Verboom, G.A., Forster, P.I., Kallunki, J., and Duretto, M. 2021. A new subfamily classification of the Citrus family (Rutaceae) based on six nuclear and plastid markers. Taxon, 70:1035-1061. https://doi.org/10.1002/tax.12543

Armbruster, W.E., Debevec, E.M., and Willson, M.F. 2002. Evolution of syncarpy in angiosperms: theoretical and phylogenetic analyses of the effects of carpel fusion on offspring quantity and quality. Journal of Evolutionary Biology, 15:657-672. https://doi.org/10.1046/j.1420-9101.2002.00414.x

Bachelier, J.B. and Endress, P.K. 2008. Floral structure in Kirkia (Kirkiaceae) and its systematic position in Sapindales. Annals of Botany, 102:539-550. https://doi.org/10.1093/aob/mcn139

Bachelier, J.B. and Endress, P.K. 2009. Comparative floral morphology and anatomy of Anacardiaceae and Burseraceae (Sapindales), with a special focus on gynoecium structure and evolution. Botanical Journal of the Linnean Society, 159:499-571. https://doi.org/10.1111/j.1095-8339.2009.00959.x

Crane, P.R., Manchester, S.R., and Dilcher, D.L. 1991. Reproductive and vegetative structure of Nordenskioldia (Trochodendraceae), a vesselless dicotyledon from the early Tertiary of the Northern Hemisphere. American Journal of Botany, 78:1311-1334. https://doi.org/10.1002/j.1537-2197.1991.tb12599.x

Dickison, W.C. and Baas, P. 1977. The morphology and relationships of Paracryphia (Paracryphiaceae). Blumea: Biodiversity, Evolution and Biogeography of Plants, 23:417-438. 
Dowelde, A.B. 1998. Carpology, seed anatomy and taxonomic relationships of Tetracentron (Tetracentraceae) and Trochodendron (Trochodendraceae). Annals of Botany, 82:413-443. https://doi.org/10.1006/anbo.1998.0679

Doyle, J.A. and Endress, P.K. 2011. Tracing the early evolutionary diversification of the angiosperm flower, p. 88-119. In Wanntorp, L., Ronse De Craene, L.P. (eds.), Flowers on the Tree of Life. Cambridge University Press, New York. https://doi.org/10.1017/cbo9781139013321.004

Endress, P.K. 1982. Syncarpy and alternative modes of escaping disadvantages of apocarpy in primitive angiosperms. Taxon, 31:48-52. https://doi.org/10.2307/1220588

Endress, P.K. 1986. Floral structure, systematics and phylogeny in Trochodendraceae. Annals of the Missouri Botanical Garden, 73:297-324. https://doi.org/10.2307/2399115

Endress, P.K. 1993. Trochodendraceae, p. 599-602. In Kubitzki, K. (ed.), The Families and Genera of Vascular Plants. Volume II. Springer, New York. https://doi.org/10.1007/978-3-662-02899-5_74

Endress, P.K. 1997. Relationships between floral organization, architecture, and pollination mode in Dillenia (Dilleniaceae). Plant Systematics and Evolution, 206:99-118. https://doi.org/10.1007/bf00987943

Endress, P.K. 2001a. Origins of flower morphology. Journal of Experimental Zoology, 291:105115. https://doi.org/10.1002/jez.1063

Endress, P.K. 2001b. The flowers in extant basal angiosperms and inferences on ancestral flowers. International Journal of Plant Sciences, 162:1111-1140. https://doi.org/10.1086/321919

Endress, P.K. 2006. Angiosperm floral evolution: morphological developmental framework. Advances in Botanical Research, 44:1-61. https://doi.org/10.1016/s0065-2296(06)44001-5

Endress, P.K. 2011. Evolutionary diversification of the flowers in angiosperms. American Journal of Botany, 98:370-396. https://doi.org/10.3732/ajb.1000299

Endress, P.K. 2014. Multicarpellate gynoecia in angiosperms: occurrence, development, organization and architectural constraints. Botanical Journal of the Linnean Society, 174:143. https://doi.org/10.1111/boj.12099

Endress, P.K. and Igersheim, A. 2000. Gynoecium structure and evolution in basal angiosperms. International Journal of Plant Sciences, 161:211-223. https://doi.org/10.1086/317572

Endress, P.K. and Doyle, J.A. 2009. Reconstructing the ancestral angiosperm flower and its initial specializations. American Journal of Botany, 96:22-66. https://doi.org/10.3732/ajb.0800047

Engler, A. 1897. Rutaceae, p. 296. In Engler, A. and Prantl, K.A. (eds.), Die Natürlichen Pflanzenfamilien nebst ihren Gattungen und wichtigeren Arten, insbesondere den Nutzpflanzen. Engelmann, Leipzig.

Friis, E.M., Pedersen, K.R., and Crane, P.R. 2001. Fossil evidence of water lilies (Nymphaeales) in the Early Cretaceous. Nature, 410(6826):357-360. https://doi.org/10.1038/35066557

Friis, E.M., Pedersen, K.R., von Balthazar, M., Grimm, G.W., and Crane, P.R. 2009. Monetianthus mirus gen. et sp. nov., a nymphaealean flower from the Early Cretaceous of Portugal. International Journal of Plant Sciences, 170:1086-1101. https://doi.org/10.1086/ 605120

Friis, E.M., Crane, P.R., and Pedersen, K.R. 2011. Early flowers and angiosperm evolution. New York, Cambridge University Press. https://doi.org/10.1017/cbo9780511980206

Heřmanová, Z., Kvaček, J., and Friis, E.M. 2011. Budvaricarpus serialis Knobloch \& Mai, an unusual new member of the Normapolles complex from the Late Cretaceous of the Czech Republic. International Journal of Plant Sciences, 172:285-293. https://doi.org/10.1086/657278

Heřmanová, Z., Dašková, J., Ekrt, B., and Kvaček, J. 2017. Zlivifructus gen. nov., a new member of the Normapolles complex. Review of Palaeobotany and Palynology, 246:177-184. https://doi.org/10.1016/j.revpalbo.2017.06.012

Heřmanová, Z., Kvaček, J., and Friis, E.M. 2021. Plant mesofossils from the Late Cretaceous Klikov Formation, the Czech Republic. Fossil Imprint, 77:256-270. https://doi.org/10.37520/fi.2021.018

Igersheim, A. and Endress, P.K. 1997. Gynoecium diversity and systematics of the Magnoliales and winteroid. Botanical Journal of the Linnean Society, 124:213-271. https://doi.org/10.1111/j.1095-8339.1997.tb01792.x 
Igersheim, A. and Endress, P.K. 1998. Gynoecium diversity and systematics of the paleoherbs. Botanical Journal of the Linnean Society, 127:289-370. https://doi.org/10.1111/j.1095-8339.1998.tb02102.x

Kaul, R.B. 1976. Conduplicate and specialized carpels in the Alismatales. American Journal of Botany, 63:175-182. https://doi.org/10.2307/2441697

Manchester, S.R., Crane, P.R., and Dilcher, D.L. 1991. Nordenskioldia and Trochodendron (Trochodendraceae) from the Miocene of northwestern North America. Botanical Gazette, 152:357-368. https://doi.org/10.1086/337898

Manchester, S.R., Kvaček, Z., and Judd, W.S. 2021. Morphology, anatomy, phylogenetics and distribution of fossil and extant Trochodendraceae in the Northern Hemisphere. Botanical Journal of the Linnean Society, 195:467-484. https://doi.org/10.1093/botlinnean/boaa046

Nishida, H. 1994. Elsemaria, a late Cretaceous angiosperm fructification from Hokkaido, Japan, p. 123-135. In Endress P.K. and Friis E.M. (eds.), Early Evolution of Flowers. Springer, Vienna. https://doi.org/10.1007/978-3-7091-6910-0_7

Nuraliev, M.S., Oskolski, A.A., Sokoloff, D.D., and Remizowa, M.V. 2010. Flowers of Araliaceae: structural diversity, developmental and evolutionary aspects. Plant Diversity and Evolution, 128:247-268. https://doi.org/10.1127/1869-6155/2010/0128-0012

Nuraliev, M.S., Degtjareva, G.V., Sokoloff, D.D., Oskolski, A.A., Samigullin, T.H., and ValiejoRoman, C.M. 2014. Flower morphology and relationships of Schefflera subintegra (Araliaceae, Apiales): an evolutionary step towards extreme floral polymery. Botanical Journal of the Linnean Society, 175:553-597. https://doi.org/10.1111/boj.12188

Nuraliev, M.S., Sokoloff, D.D., Karpunina, P.V., and Oskolski, A.A. 2019. Patterns of diversity of floral symmetry in angiosperms: a case study of the order Apiales. Symmetry, 11:473. https://doi.org/10.3390/sym11040473

Remizowa, M.V., Sokoloff, D.D., and Rudall, P.J. 2010. Evolutionary history of the monocot flower. Annals of the Missouri Botanical Garden, 97:617-645. https://doi.org/10.3417/2009142

Ronse De Craene, L.P. and Smets, E.F. 1998. Meristic changes in gynoecium morphology, exemplified by floral ontogeny and anatomy, p. 85-112. In Owens, S.J. and Rudall, P.J. (eds.), Reproductive biology in systematics, conservation and economic botany. Kew, Royal Botanic Gardens.

Rozefelds, A.C., Dettmann, M.E., Clifford, H.T., Hocknull, S., Newman, N., Godthelp, H., Hand, S.J., and Archer M. 2015. Traditional and computed tomographic (CT) techniques link modern and Cenozoic fruits of Pleiogynium (Anacardiaceae) from Australia. Alcheringa, 39:24-39. https://doi.org/10.1080/03115518.2014.951916

Sauquet, H., von Balthazar, M., Magallón, S., Doyle, J.A., Endress, P.K., Bailes, E.J., Barroso de Morais, E., Bull-Hereñu, K., Carrive, L., Chartier, M., Chomicki, G., Coiro, M., Cornette, R., El Ottra, J.H.L., Epicoco, C., Foster, C.S.P., Jabbour, F., Haevermans, A., Haevermans, T., Hernández, R., Little, S.A., Löfstrand, S., Luna, J.A., Massoni, J., Nadot, S., Pamperl, S., Prieu, C., Reyes, E., dos Santos, P., Schoonderwoerd, K.M., Sontag, S., Soulebeau, A., Staedler, Y., Tschan, G.F., Wing-Sze Leung, A., and Schönenberger, J. 2017. The ancestral flower of angiosperms and its early diversification. Nature Communications, 8, 16047. https:/ /doi.org/10.1038/ncomms16047

Sauquet, H., von Balthazar, M., Doyle, J.A., Endress, P.K., Magallón, S., Staedler, Y., and Schönenberger, J. 2018. Challenges and questions in reconstructing the ancestral flower of angiosperms: a reply to Sokoloff et. al. American Journal of Botany, 105:127-135. https://doi.org/10.1002/ajb2.1023

Slánská, J. 1974. Continental Cretaceous and Tertiary Sedimentation in the South Bohemian Basin. Neues Jahrbuch für Geologie und Paläontologie, Abhandlungen, 146:385-406.

Slánská, J. 1976. A red-bed formation in the South Bohemia Basins, Czechoslovakia. Sedimentary Geology, 15:135-164. https://doi.org/10.1016/0037-0738(76)90041-5

Schneider, E.L. and Williamson, P.S. 1993. Nymphaeaceae, p. 486-493. In Kubitzki, K., Bittrich, V., and Rohwer, J.G. (eds.), The Families and Genera of Vascular Plants. Volume 2. Springer, Berlin. https://doi.org/10.1007/978-3-662-02899-5_57

Schönenberger, J., von Balthazar, M., López Martínez, A., Albert, B., Prieu, C., Magallón, S., and Sauquet, H. 2020. Phylogenetic analysis of fossil flowers using an angiosperm-wide data set: proof-of-concept and challenges ahead. American Journal of Botany, 107:1-16.

https://doi.org/10.1002/ajb2.1538 
Simpson, M.G. 2010. Plant Systematics. 2nd edition. Academic Press, Elsevier. https://doi.org/10.1016/C2009-0-02260-0

Stebbins, G. 1974. Flowering plants. Evolution above the species level. Harvard University Press. https://doi.org/10.4159/harvard.9780674864856

Stevens, P.F. 2001 onwards. Angiosperm Phylogeny Website. Version 14, July 2017. http://www.mobot.org/MOBOT/research/APweb/

Váchová, Z. and Kvaček, J. 2009. Palaeoclimate analysis of the flora of the Klikov Formation, Upper Cretaceous, Czech Republic. Bulletin of Geosciences, 2:257-268. https://doi.org/10.3140/bull.geosci.1100

von Balthazar, M., Pedersen, K.R., Crane, P.R., and Friis, E.M. 2008. Carpestella lacunata gen. et sp. nov., a new basal angiosperm flower from the Early Cretaceous (Early to Middle Albian) of eastern North America. International Journal of Plant Sciences, 169:890-898. https://doi.org/10.1086/589692

Wang, Y.H., Ferguson, D.K., Feng, G.P., Wang, Y.F., Zhilin, S.G., Li C.S., and Ablaev, A.G. 2009. The phytogeography of the extinct angiosperm Nordenskioeldia (Trochodendraceae) and its response to climate changes. Palaeogeography, Palaeoclimatology, Palaeoecology, 280:183-192. https://doi.org/10.1016/j.palaeo.2009.05.019

Williams, E.G., Sage, T.L., and Thien, L.B. 1993. Functional syncarpy by intercarpellary growth of pollen tubes in a primitive apocarpous angiosperm, Illicium floridanum (Illiciaceae). American Journal of Botany, 80:137-142. https://doi.org/10.2307/2445031 